Jennifer Altehenger, University of Oxford, Author Accepted Manuscript

E-mail: jennifer.altehenger@history.ox.ac.uk

\title{
Industrial and Chinese: Exhibiting Mao's China at the Leipzig Trade Fairs ${ }^{1}$
}

In 1959, China took centre stage at the annual Leipzig spring trade fair. It was the eighth year that the People's Republic of China participated in the fairs, one of the most important Comecon fairs and - following the organisers' own description - the 'meeting place of East and West'. With its pavilion only second in size to that of the Soviet Union, China was an established presence on the expansive fair grounds in the heart of the city. Every year, long trains with dozens of rail waggons travelled weeks from Beijing to Leipzig, carrying new industrial machinery, electrical appliances, samples of raw materials, metals, and agricultural products, textiles, furs, tea, spices and luxury items such as ivory carvings, enamel, and jade. The Chinese exhibition was popular, leading Reinhold Henning to write in his 1959 guidebook Leipzig: the World's Showcase: 'no visitor will miss visiting the China Pavilion on the spring fair. One needs to have a bit of patience though. Especially on Sundays, the demand is so high that the hall, designed in the style of old Chinese architecture, has to be closed'. ${ }^{2}$ More than just a space for trade deals and visitor amusement, the wealth of objects on display made the fairs, he concluded, 'a site of practical object lessons. The rapid speed and determination with which the people in between the Elbe and the Pacific Ocean are working to realise the tasks they have set themselves makes an inescapable impression on everyone in Leipzig.

\footnotetext{
${ }^{1}$ Research for this article was supported by a British Academy/Leverhulme Small Research Grant (SG152939), the Sino-British Fellowship Trust, and King's College London. I am grateful to colleagues at the Hong Kong Asia Society, M+ Museum, Fudan University, and the organisers of the V\&A/RCA History of Design seminar and Oxford China Center seminar for inviting me to present some of the research on which this article is based. Many colleagues have generously provided advice, sources, and encouragement. In particular, I thank Karl Gerth, Arunabh Ghosh, Denise Ho, Shen Yu, Sarah Teasley, Sören Urbansky, Jennifer Wong, Frauke Gränitz (Leipziger Messe Unternehmensarchiv) and the archivists at the Saxonian State Archives in Dresden and Leipzig for their support.

${ }^{2}$ Reinhold Henning, Leipzig: Schaufenster der Welt (Berlin 1959), 20.
} 
Especially when in the Chinese Pavilion one is assured that the socialist camp will emerge victoriously from the peaceful competition of the two world economic systems'. ${ }^{3}$ With such material proof of the strength of socialist unity, Henning confidently anticipated the ascendancy of the socialist world. Both the German Democratic Republic and the People's Republic of China (PRC) were celebrating their ten-year anniversary in 1959, and his guidebook was evidence of a decade during which the Chinese pavilion and annual PRC delegations had played an important role in the performance of socialist internationalism. Having China participate was essential. China was the world's most populous country, now turned socialist, and the Chairman of the Chinese Communist Party Mao Zedong was one of the longest serving revolutionaries fighting for world communism. Exhibitions including China showed the promise and strength of socialism; exhibitions without China risked speculation about the state of socialist brotherhood.

When Henning wrote in 1959, however, the unity of this world was crumbling beneath the shiny exhibition surfaces. Once a celebration, his account soon became testimony of how quickly this apparent unity deteriorated when tensions between China and the Soviet Union mounted, leading to the Sino-Soviet split during the early 1960s. Within a few years the Leipzig fairs transformed into a different kind of space for the meeting of 'East and West'. Competition between 'two world economic systems' became an amorphous, sometimes triangular competition between China, the Soviet Union, and other states. Little did Henning know that the year 1959 was to be one of the last years that the PRC exhibited at Leipzig on the grand scale he had described. Between 1962 and 1966, with the Sino-Soviet split apparent to all, Chinese delegations continued to travel to the fairs frequently, but these delegations were a combination of propaganda to show Chinese goodwill to fix discord among the socialist world and fact-finding missions to gather information about other countries' scientific and technological advances. At Leipzig,

\footnotetext{
${ }^{3}$ Ibid., 123.
} 
delegates from all socialist countries now performed the diplomatic dance of allegiances, trying to steer to political safety while keeping as many trade avenues open as possible.

This article examines the history of the China pavilion from early enthusiasm to the years of the Sino-Soviet split. It focuses on discussions about how to design the pavilion's exterior and interior, how to display objects, how to organise events and activities, and how to make China part of the larger exhibition. These discussions illustrate that the question how China would take on material form at Leipzig was contentious from the start. The problem was that China was at once a revolutionary state of enormous political and economic significance, and a state that Josef Stalin had determined was too poorly developed to transit immediately to socialism. ${ }^{4}$ The Leipzig fairs consequently became an annual opportunity for both the GDR and PRC governments to situate China on the ladder of historical development according to the sometimes-competing canons of Marxism-Leninism and Mao Zedong Thought.

This ladder, however, was continuously reconfigured and it served different needs over time. ${ }^{5}$ Drawing on archival records of GDR government ministries, the Leipzig Fair Office, PRC ministries, and municipal governments in Beijing and Shanghai, as well as on Chinese and German internal and public reportage, the article shows how the PRC and GDR governments and the Leipzig Fair Office pursued different objectives with regard to China's exhibitions at Leipzig; objectives that sometimes aligned and at other times diverged. ${ }^{6}$ The CCP wanted to project a strong, sovereign, and industrialising Chinese state and nation. ${ }^{7}$ It had assumed a rich legacy of Chinese international exhibitions that

\footnotetext{
${ }^{4}$ For histories of the early PRC that touch on this dilemma see A.G. Walder, China under Mao. A Revolution Derailed (Cambridge, MA, 2015), also J. Brown and P. G. Pickowicz, eds, Dilemmas of Victory. The Early Years of the People's Republic of China (Cambridge, MA, 2007).

${ }_{6}^{5}$ Ho, Curating Revolution, 17.

${ }^{6}$ The article relies mostly on German-language archival sources because comparative accessible holdings in China are scarce. I was unable to find relevant documents in the archives of the Chinese Ministry of Foreign Affairs, though if they do make more documents available again in future these might provide further useful insights.

${ }^{7}$ The role of national identity in trade exhibitions is discussed in Raizman and Robey (eds) Expanding Nationalism at World's Fairs, L. Siegelbaum, 'Sputnik Goes to Brussels: The Exhibition of a Soviet Technological Wonder', Journal of Contemporary History, 47, 1 (2012), 120-136. C. Giustino
} 
dated back to the second half of the nineteenth century. Qing as well as Republican China had participated in international trade fairs in London, Paris, Vienna, Panama and other places, and Republican China had a brief presence also in Leipzig. Much of this legacy was important for political, diplomatic and economic purposes, yet the $\mathrm{CCP}$ also considered it deeply troubled: it was part of China's 'semi-colonial' past and its exploitation by imperialist powers. ${ }^{8}$ The example of the Leipzig Fairs highlights that the CCP increasingly saw trade fairs as an opportunity to redefine what 'Chinese' meant internationally. Elaborate displays of heavy machinery and industrial as well as agricultural accomplishments would prove that de-colonized, sovereign 'New China' commanded the international material language of industrial and technological development; a message all parties were keen to transmit. ${ }^{9}$

Light industry, handicraft and luxury goods, by contrast, were more ambivalent objects in discussions about how to display China. Western consumers traditionally associated silk, jade, fur, tea, porcelain, and bamboo goods with China and with the 'oriental'. It was

'Industrial Design and the Czechoslovak Pavilion at EXPO '58: Artistic Autonomy, Party Control and Cold War Common Ground', Journal of Contemporary History, 47, 1 (2012), 185-212. K. Pence, 'Showcasing Cold War Germany in Cairo: 1954 and 1957 Industrial Exhibitions and the Competition for Arab Partners', Journal of Contemporary History, 47, 1 (2012), 69-95.

${ }^{8}$ For a rich discussion of late imperial and Republican period Chinese international exhibitions, and the problem of how to represent China as a nation and culture, see S.R. Fernsebner, 'Material Modernities: China's Participation in World's Fairs and Expositions', unpublished PhD thesis, University of California, San Diego, 2002, and S.R. Fernsebner, 'When the Local is the Global: Case studies in early twentieth-century Chinese exposition projects', in D. Raizman and E. Robey (eds) Expanding Nationalism at World's Fairs: Identity, Diversity, and Exchange, 1851-1915 (London 2017). Historiography on Chinese exhibitions before 1949 further includes B. Doar, 'China's Participation in World Fairs from the Perspective of Art History: London 1851 and Beyond', Journal of the Oriental Society of Australia, 47 (2015), 138-164. L. Koivunen, 'Between the Material Object and Its Representation: Chinese Garments on Non-Chinese Bodies at the Sino-African Exhibition of 19111912 in Finland', Journal of Design History, 31, 2 (2018), 184-201. C. Roskam, 'Situating Chinese Architecture within "A Century of Progress": The Chinese Pavilion, the Bendix Golden Temple, and the 1933 Chicago World's Fair', Journal of the Society of Architectural Historians, 71, 3 (2014), 347 371. C. A. Christ, 'The Sole Guardians of the Art Inheritance of Asia: Japan and China at the 1904 St Louis World's Fair', Positions: East Asia Cultures Critique, 8, 3 (2000), 675-709. I. Cortinovis: 'China at the St. Louis World's Fair', Missouri Historical Review, 72 (1977), 59-66. B. Liang, 'Minzhu zhongguo shijie fumei de yixie jingji huodong: zhongguo yu banama taiping yang wanguo bolanhui', Jindaishi yanjiu, 1 (1998), 81-99. B. Vennman, 'Dragons, Dummies and Royals: China at American World's Fairs', Gateway Heritage, 17, 2 (1996), 16-31. R. Rydell, All the World's a Fair: Visions of Empire at American International Expositions, 1876-1916 (Chicago 1984), 30-32. H. Hur, 'Staging Modern Statehood: World Exhibitions and the Rhetoric of Publishing in Late Qing China, 1851-1910', unpublished $\mathrm{PhD}$ thesis, University of Illinois at Urbana-Champaign, 2012.

${ }^{9}$ See Davis, 'From the Great Exhibition to EXPO 2000'; Geppert, 'Welttheater'; Geppert, Coffey and Lau, 'International Exhibitions, Expositions Universelles and World Fairs, 1851-2005: A Bibliography'. 
more difficult to use these to change popular perceptions and the CCP feared that some of them might perpetuate oriental stereotypes. ${ }^{10}$ The CCP, on the one hand, therefore wanted these products to have a minor presence in the exhibition overall. On the other hand, however, selected light industry export products were supposed to be promoted actively and especially for consumption by ordinary citizens. This was done to maximise trade gains and to show that a rapidly industrialising China had much to give to the world and to the socialist bloc. ${ }^{11}$ The officials at the fair office, meanwhile, wanted light industry and handicraft goods to have a much more prominent place in the Chinese exhibition, simply because they attracted larger visitor crowds than industrial machinery. Each Chinese exhibition thus required renewed and increasingly complicated negotiations about the importance of different objects and the story they were to tell of China's development. These negotiations influenced how the GDR, the USSR, and other socialist countries positioned themselves and their developmental stories.

By contributing to existing scholarship on the history of the Leipzig fairs, this article illustrates how China became crucial to the positioning of Leipzig as the self-professed meeting point of 'East and West' during the second half of the twentieth century, but also how it challenged this narrative at different times. ${ }^{12}$ It reconstructs how, for several weeks each year, Chinese delegations helped turn Leipzig into one of the world's major 'sites of convergence' for cultures, ideologies, political systems, trade interests, and consumer aspirations. ${ }^{13}$ This adds to a growing field of scholarship that has sought to restore the

\footnotetext{
${ }^{10}$ S.R. Fernsebner, 'Material Modernities: China's Participation in World's Fairs and Expositions'.

${ }^{11}$ On the significance of the 'Chinese' identity of 'Chinese' goods see K. Gerth, China Made. Consumer Culture and the Creation of the Nation (Cambridge, MA 2004).

${ }^{12}$ For historical analyses of the Leipzig fairs after 1945 see K. Pence, "'A World in Miniature": The Leipzig Trade Fairs in the 1950s and East German Consumer Citizenship', in D.F. Crew (ed.) Consuming Germany in the Cold War: Leisure, Consumption and Culture (Oxford 2003), 21-50. K. Rudolph and J. Wüstenhagen, Grosse Politik-Kleine Begegnungen: die Leipziger Messe im Ost-West Konflikt (Berlin 2006). There are few English or German language historical accounts that discuss the China Pavilion. One of the few exceptions is Katherine Pence who mentions China briefly in her chapter as part of her discussion of international exhibitors at Leipzig, Ibid., 27.

${ }^{13}$ I borrow this helpful term from G. Péteri, 'Sites of Convergence: The USSR and Communist Eastern Europe at International Fairs Abroad and at Home', Journal of Contemporary History, 47, 1 (2012), 312. The literature on international exhibitions and world's fairs is extensive. See, for example, A.
} 
PRC to the history of international fairs following World War Two. ${ }^{14}$ The particular

example of China at Leipzig, moreover, deepens our understanding of how cultural and

economic factors interacted to shape Sino-GDR relations ${ }^{15}$, and adds a further case study

to the local and cultural history of the Sino-Soviet split. ${ }^{16}$ Finally, looking at the China

Geppert, Fleeting Cities. Imperial Expositions in Fin-de-Siecle Europe (London 2010); P. Greenhalgh, Ephemeral Vistas: The Expositions Universelles, Great Exhibitions, and World Fairs, 1851-1939 (Manchester, 1988); J. E. Findling and K. D. Pelle, eds, Historical Dictionary of World's Fairs and Expositions, 1851-1988 (Westport, CT, 1988); R. W. Rydell, World of Fairs. The Century-of-Progress Expositions (Chicago, 1993); Peter. H. Hoffenberg, An Empire on Display. English, Indian, and Australian Exhibitions from the Crystal Palace to the Great War (Berkeley, 2001); S. Schuster, 'The World's Fairs as Spaces of Global Knowledge: Latin American's Archaeology and Anthropology in the Age of Exhibitions', Journal of Global History, 13, 1 (2018), 69-93. For overviews of the scholarship on fairs and exhibitions see: J. R. Davis, 'From the Great Exhibition to EXPO 2000. The History of Display', Bulletin of the German Historical Institute London vol. 22, no. 2 (2000): 7-19 and A. C.T. Geppert, 'Welttheater: Die Geschichte des europäischen Ausstellungswesens im 19. und 20.

Jahrhundert: Ein Forschungsbericht', Neue Politische Literatur no. 1 (2002): 10-61 as well as A. C.T. Geppert, J. Coffey and T. Lau, 'International Exhibitions, Expositions Universelles and World Fairs, 1851-2005: A Bibliography', http://www.geschkult.fu-

berlin.de/e/fmi/astrofuturismus/publikationen/Geppert_-_Expo_bibliography_3ed.pdf.

${ }^{14}$ A point also made in A. Jersild, 'Socialist Exhibits and Sino-Soviet Relations, 1950-60', Cold War History vol.18, no. 3 (2018): 275-89, one of the few detailed studies of Chinese exhibitions after 1945. 15 The study of Sino-GDR relations has been dominated by economic, political, and diplomatic perspectives. For examples of this scholarship see J. Ge, 'Shilun xin Zhongguo yu Minzhu Deguo zaoqi maoyi guanxi (1950-1955) [On the early economic relations of New China and Democratic Germany]', Zonggong dangshi yanjiu, 11 (2016), 70-83, J. Ge, 'Lun 1950 niandai Zhongguo duiyu chengren 'liangge Deguo' de taidu [China's approach to recognising the 'Two Germanies' during the 1950s]', Lishi jiaoxue wenti 3 (2016), 77-83. W. Kirby, 'China's Internationalization in the Early People's Republic: Dreams of a Socialist World Economy', The China Quarterly, 188 (2006), 870-890; W. Meissner (ed.), Die DDR und China 1949 bis 1990: Politik, Wirtschaft, Kultur: eine Quellensammlung (Berlin 1995); A. Port, 'Courting China, Condemning China: East and West German Cold War Diplomacy in the Shadow of the Cambodian Genocide', German History, 33, 4 (2015), 588-608. On social and cultural historical aspects see N. Volland, 'Translating the Socialist State: Cultural Exchange, National Identity, and the Socialist World in the Early PRC', Twentieth-Century China, 33, 2 (2008), 51-72. N. Volland, Socialist Cosmopolitanism: The Chinese Literary Universe, 1945-1965 (New York 2017). A. Shuman, "From Soviet Kin to Afro-Asian Leader: The People's Republic of China and International Sport in the early 1960s", Comparativ, vol. 23, Iss. 3 (2013): 78-99; A. Shuman,"Friendship is solidarity: The Chinese ping pong team visits Africa in 1962," in Simon Rofe, ed., Sport and Diplomacy: Games within Games (Manchester, forthcoming 2018); M. Wobst, Die Kulturbeziehungen zwischen der DDR und der VR China, 1949-1990: kulturelle Diversität und politische Positionierung (Münster 2004). D. Tompkins, 'The East is Red? Images of China in East Germany and Poland through the Sino-Soviet Split', Zeitschrift für Ostmitteleuropa-Forschung, 62, 3 (2013), 393-424. D. Tompkins, 'Red China in Central Europe: Creating and Deploying Representations of an Ally in Poland and the GDR', in P. Babiracki and A. Jersild (eds) Socialist Internationalism in the Cold War: Exploring the Second World (London 2016), 273-301. Q. Slobodian, 'The Maoist Enemy: China's Challenge in 1960s East Germany', Journal of Contemporary History, 51, 3 (2016), 635-659; Q. Slobodian, 'Badge Books and Brand Books: The 'Mao Bible' in the Two Germanies" in: A. C. Cook, ed., Mao's Little Red Book: A Global History (Cambridge, 2014), 206-24.

${ }^{16}$ Major works include Chen Jian, Mao's China and the Cold War (Charlotte, NC 2010). L. Lüthi, The Sino-Soviet Split: Cold War in the Communist World (Princeton, NJ 2008); S. Radchenko, Two Suns in the Heavens: The Sino-Soviet Struggle for Supremacy, 1962-1967 (Washington, DC 2009); Z. Shen and D. Li, After Leaning to One Side: China and its Allies in the Cold War (Stanford 2011); S. Zhang, Economic Cold War: America's Embargo against China and the Sino-Soviet Alliance, 1949-1963 (Washington, DC 2001). In recent years, there has been a steady increase in works that examine China's interactions with socialist world before and after the cooling of relations with the Soviet Union 
pavilion not merely as a site of trade and at its objects not merely as goods suggests ways in which materiality, often taken for granted, can be a vantage point from which to examine post-war China's interactions with other countries. ${ }^{17}$

[line break]

The GDR was established on 7 October 1949, one week after Mao proclaimed the founding of the PRC at Beijing's Tian'anmen Gate. The GDR government was anxious for the Leipzig fairs to become a venue to present the glory of a new Germany to the world, and to help economically and politically stabilize a socialist state in its infancy. For that to work, the new PRC government had to be convinced to have a Chinese exhibition as soon as possible and thus assume the legacy of Chinese governments that had exhibited at Leipzig before the war. After an initial attempt to have China join the 1950 spring fair with a collective exhibition - an attempt thwarted by the fact that the GDR and China had yet to exchange diplomatic representatives - the fair office lobbied heavily for China to participate. ${ }^{18}$ It asked GDR government delegation members who were travelling to China to praise the fairs and show photos of past exhibitions. It sent letters to the Chinese Ministry of Foreign Affairs promising that an exhibition would bring many advantages for China: it would be easier to discuss trade deals in person, address questions, and accommodate any special requests the Chinese government may

from a variety of angles including scientific exchanges and sports' events, see for example, P. Babiracki and A. Jersild, eds, Socialist Internationalism in the Cold War: Exploring the Second World (London 2016); Y. Li, China's Soviet Dream: Propaganda, Culture, and Popular Imagination (London 2018); and G. Barrett, 'China's 'People's Diplomacy' and the Pugwash Conferences, 1957-1964', Journal of Cold War Studies, vol. 20, no. 1 (2018): 140-69.

${ }^{17}$ On the relevance of objects to the study of Mao Era China see D. Ho, Curating Revolution: Politics on Display in Mao's China (Cambridge 2017). On gifts and material goods in diplomatic exchanges between Asia and Europe see G. Riello, Z. Biedermann, and A. Gerritsen, Global Gifts: The Material Culture of Diplomacy in Early Modern Eurasia (Cambridge 2017), especially 'Introduction: Global Gifts and the Material Culture of Diplomacy in Early Modern Eurasia', 1-33.

${ }^{18}$ Sächsisches Staatsarchiv, Staatsarchiv Leipzig (StA-L hereafter), 21000 VEB LMA (II), No. 1282 Telegram, 13 December 1949. StA-L, 21000 VEB LMA (II), No. 1282, 'Auszug aus der Aktennotiz über die Besprechung mit Frau Staimer - Dr. Kromrey (Dr. Pröpper-Krüger) betr. Messeabkommen am 20.1.1950', 23 January 1950. There was some disappointment when the PRC did not exhibit at Leipzig in 1950. Following a mistaken press report in West German news in March 1950, West German firms had prepared for an official delegation from China that had the authorization to make purchase on behalf of the PRC government. StA-L, 21000 VEB LMA (II), No. 1282, 'An die Berliner Geschäftsstelle des Leipziger Messeamtes, Betrf: Vertretung der Volksrepublik China', 22 March 1950. 
have when purchasing new technologies or products. It would also give a 'favourable impetus' to the on-going negotiations over a Sino-GDR trade treaty. Travel, moreover, would be convenient--the official fair entry passes doubled as a visa. ${ }^{19}$ In case these benefits were not convincing enough, they added that the 'generous participation' of the Soviet Union and other socialist states with 'substantial collective exhibitions' had had 'clear economic success and at the same time a strong political effect' ${ }^{20}$ China could not afford to miss out.

The PRC government took its time to decide; it was occupied with the new war in Korea, the effects of the UN trade embargo, and wide-ranging domestic mass campaigns aimed at 'enemies of the people'. The restless fair office only received a positive answer in late December 1950, three months before the spring fair. ${ }^{21}$ China's participation was a political victory, yet the office now faced the logistical challenge of pulling everything together in little time. China would receive 524 square meters of exhibition space within the larger Hall X, the Hall of the Foreign Nations. China's smaller exhibition in Hall X would be adjacent to the CSR (2000 sqm), Poland (1500 sqm), Hungary (1500 sqm), Romania (1000 sqm), and Bulgaria (500 sqm). ${ }^{22}$ To allow China sufficient funds to pay for the exhibition, including rent, construction costs, hotel rooms, and interpreter fees, the fair office and GDR Ministry of Foreign and Inner German Trade (MAI hereafter)

\footnotetext{
${ }^{19}$ StA-L, 21000 VEB LMA (II), No. 1282, 570043 „Auszug aus der Aktennotiz China -Besprechung mit Herrn Makower und Herrn Dr. Pröpper / Krüger am 17.5.1950' , 22 May 1950. See also StA-L, 21000 VEB LMA (II), No. 1282, 'Brief an das Ministerium für Außenhandel der VR China, Peiping /China, Betr: "Beteiligung der Volksrepublik China an der LEIPZIGER MESSE"', 20 May 1950.

${ }^{20}$ StA-L, 21000 VEB LMA (II), No. 1282, 'Brief an das Ministerium für Außenhandel der VR China', 20 May 1950.

${ }^{21}$ The office had repeatedly written to the GDR trade delegation in Beijing and to the PRC Diplomatic Mission in East Berlin. See StA-L, 21000 VEB LMA (II), No. 1282, Letter from Dr Pröpper, Leipzig Fair Office, to Mr Makower at the German trade delegation for the PR China, 8 September 1950. StAL, 21000 VEB LMA (II), No. 1282, 'Auszug aus der Aktennotiz Besprechung mit Minister Ziller, Ministerium für Maschinenbau am 5.12.1950', 6 December 1950, and StA-L, 21000 VEB LMA (II), No. 1282,'Aktennotiz über den Anruf von Herrn Krüger, Berliner Geschäftsstelle, am 29.12.1950'. ${ }^{22}$ StA-L, 21000 VEB LMA (II), No. 1282, Letter from Krüger to the Diplomatic Mission of the PR China in Berlin, 'Betr: Leipziger Messe im Frühjahr 1951', no date.
} 
arranged for a credit of 650,000 German Marks with the German Central Bank. ${ }^{23}$ Trains carrying over 300 carts with exhibition objects, meanwhile, left Beijing.

The design of the first post-war Chinese exhibition was of utmost importance. Within the Hall, it was placed, as one letter assured the Chinese Ministry of Trade, at a 'very advantageous point'. ${ }^{24}$ A good design promised to raise the appeal of the fair, and it would present the young People's Republic - a country still unfamiliar and distant to many - in a positive light. The fair office commissioned architects, stall designers, carpenters, and decorators. The Chinese government was responsible for 'the decoration of the exhibition stall, for the installation of the fair goods, and for the procurement of necessary furniture such as tables, pedestals, and shelves'. ${ }^{25} \mathrm{~A}$ first delegation including the Deputy Director of the Ministry of Trade's Foreign Trade Department Jia Shi and the artist Zhang Ding, a well-known artist who had been part of the team that designed the Chinese national emblem, travelled to East Germany in the first half of February to supervise the construction of the exhibition. ${ }^{26}$ They worked with Selman Selmanagic, a prominent architect and professor, former Bauhaus pupil, and lead designer of many of the GDR's trade fair pavilions throughout the $1950 \mathrm{~s} .{ }^{27}$ In cooperation with the VEB Deutsche Werkstätten Hellerau, Selmanagic put forward design suggestions he had first

\footnotetext{
${ }^{23}$ StA-L, 21000 VEB LMA (II), No. 1282, 'Auszug aus der Aktennotiz über den Anruf der Berliner Geschäftsstelle, Herr Krüger,' 23 January 1951. At 11 US dollars per square meter rent, the overall costs for the exhibition were estimated at about 300-350.000 German marks, see StA-L, 21000 VEB LMA (II), No. 1282, 'Niederschrift, China-Stand Besprechung, am 13.2.1951 in der Diplomatischen Mission der Volksrepublik China'. 15 February 1951. China was given the option of paying in kind as part of trade deals. StA-L, 21000 VEB LMA (II), No. 1282, 'Aktenvermerk, Unterredung mit dem chinesischen Botschaftsrat Djing Lin, am 5.2.1951', 8 February 1951.

${ }^{24}$ StA-L, 21000 VEB LMA (II), No. 1282, 'Lage und Beschreibung des Messestandes - Technische Angaben-Standbauvorschriften, Kollektivstand China', 30 December 1950.

${ }^{25}$ Ibid.

${ }^{26}$ On Zhang Ding's work designing Chinese exhibitions abroad after 1949 see Sun Jing, 'Zhang Ding yu duiwai zhanlan [Zhang Ding and China's exhibitions abroad]', Zhuangshi magazine online, 28 October 2010, URL: http://izhsh.com.cn/doc/10/0_694.html (last accessed 26 October 2018).

${ }^{27}$ For Selmanagic's biography and work see Kunsthochschule Berlin, ed, Selman Selmanagic. Festgabe zum 80. Geburtstag am 25 April 1985 (Ost-Berlin, 1985). Pence, 'Showcasing Cold War Germany in Cairo', 77. E. Rubin, 'The Form of Socialism without Ornament: Consumption, Ideology, and the Fall and Rise of Modernist Design in the German Democratic Republic', Journal of Design History, Vol. 19, No. 2 (2006): 155-68.
} 
developed in anticipation of a Chinese exhibition in 1950, and reworked these blueprints together with Zhang Ding and his team.

Designing the exhibition was a process of reconciling expectations under time constraints. China's exhibition space extended over two floors, connected by a grand staircase. In conversations with the fair organisers, Jia explained that the PRC government saw this as an 'economic-political exhibition' and wished to emphasise the 'political aspect'. Three types of objects needed to be displayed: 1) Heavy industry, especially ores, 2) Light industry products, especially silk, textiles, leather goods, and car tires, and 3) Agricultural products, especially tea, soybeans, peanuts and rice, but also furs, animal skins, egg powder and natural bristles. Bijouterie and artistic products would be included, but Jia explained that 'from the Chinese perspective these are not significant'. ${ }^{28}$ The Chinese delegation worried that the East Germans only thought of China as Asian and a source of oriental fineries, not a budding industrial nation.

These were valid concerns. Perhaps unintentionally, Selmanagic's first designs emphasised the oriental and traditional. They included twenty wood columns painted in 'ox-blood red' and glass vitrines made of pear tree wood decorated with latticed Kalopanax wood (German: Sen-esche, Chinese: ciqiu), a wood commonly found in Japan and China that was considered a precious veneer (Edelfurnier) at the time. ${ }^{29}$ Some vitrines were covered in red silk. Red rugs made of coconut fibres and red boucle carpets were laid out across the floor, and rattan chairs with red artificial leather and little teetables with red, black, and golden mosaic stones were to offer visitors a space to engage in conversation or rest. ${ }^{30}$ Selmanagic also designed a six-meter tall replica of a traditional

\footnotetext{
${ }^{28}$ StA-L, 21000 VEB LMA (II), No. 1282, 'Niederschrift, China-Stand Besprechung, am 13.2.1951 in der Diplomatischen Mission der Volksrepublik China', 15 February 1951.

${ }^{29}$ Sächsisches Staatsarchiv, Hauptstaatsarchiv Dresden (HStA-D hereafter), 11764 Deutsche Werkstätten Hellerau, no. 4858, 'Betr.: Kom. 20381 - Messe-Stand Volksrepublik China, durch Herrn Architekt Prof. Selmanagic und Herrn Buske', 4 February 1951.

${ }^{30}$ HStA-D, 11764 Deutsche Werkstätten Hellerau, no. 4858, 'Betr.: China-Ausstellung/Frühjahrsmesse 1951/Technische Messe, Halle 2', 26 January 1951, and HStA-D, 11764 Deutsche Werkstätten Hellerau, no. 4858, 'Betr.: Leipziger Frühjahrsmesse/China-Ausstellung', 15 February 1951.
} 
Chinese stone column (huabiao). ${ }^{31}$ Zhang Ding was happy with the column, but not with many of the other elements. He advised Selmanagic about 'typical Chinese forms' in order to 'avoid a lapse into Japanese elements', although the documents do not specify what this entailed. At the same time, Zhang's aim to create a distinctly Chinese exhibition had to be reconciled with the fair organizers' plans as they worried that too much 'decorative eclecticism' would 'endanger the uniform design of the display'. ${ }^{32}$ In the final design, ores, oils, fats, cotton, tea and rice therefore featured prominently on the ground floor of the exhibition. To get to the bijouterie and other fineries, visitors climbed the stairs towards a large mural of Tian'anmen (See Figure 1).

Political intricacies of layout and design were largely lost on the average visitor, however. Bijouterie, furs, and artistic products became one of the most popular parts of the exhibition after it opened on 4 March 1951. Photographs of the exhibition show people clustering in front of desirable and luxurious goods with noses almost pressed to the glass. Reporters writing about the new China Pavilion, the attraction of the season, spent as much if not more time discussing jade, enamel, and cloisonné than industrial achievements. China's other prioritized items such as peanuts and silk, too, were popular and offered exotic experiences to visitors. Writing in the Chinese journal World Knowledge, Chen Shiwu recalled how an East German young pioneer had tried peanuts for the first time at the fair. Later, the Chinese delegation gifted $360 \mathrm{~kg}$ of peanuts that were distributed among East Berlin's kindergardens. ${ }^{33}$ Such publicity was pleasing for the Chinese delegation, but they desired more than popularity: China was to be taken seriously as an industrialising and partly industrialised nation.

[line break]

\footnotetext{
${ }^{31}$ HStA-D, 11764 Deutsche Werkstätten Hellerau, no. 4858, original drawings by Selmanagic, no title. ${ }^{32}$ StA-L, 21000 VEB LMA (II), No. 1282, „Niederschrift, China-Stand Besprechung, am 13.2.1951 in der Diplomatischen Mission der Volksrepublik China'.

${ }^{33}$ Chen Shiwu, 'Sishi wan ren zheng kan Zhongguo guan -Laibixi bolanhui jishi [400,000 people vie to see the Chinese Pavilion - a chronicle of the Leipzig Fair]', Shijie zhishi, March 1951.
} 
Following its modest stall in the 1951 collective exhibition, the Chinese government became more ambitious. At the 1952 fair, China occupied over 3000 square meters of hall $\mathrm{E}$, and 1500 square meters outside space in front of the hall, which together became known as the China Pavilion. The Pavilion was one of Leipzig's main attractions over the next years. By 1956, an article in the Chinese edition of the Leipziger Messemitteilungen, the fair's regular magazine published in several languages, reviewed the first five years of Chinese exhibitions and praised the pavilion to its readers, optimistically promising that the China pavilion had become a 'faithful and vivid mirror of Chinese economic development'. Next to textile and handicraft products, consumer goods, minerals, cereals and food, one could also see 'increasingly more and increasingly refined new machinery'. ${ }^{34}$

Neither the fair organizers nor the GDR government, however, had planned on giving the PRC its own pavilion. They meant for China to be part of the socialist collective exhibitions while the Soviet Union occupied a single grand pavilion; mirroring the way Stalin conceived of the Soviet Union as the centre of the socialist world. The Chinese, meanwhile, wanted an exhibition that reflected the fact that China was second in size only to the Soviet Union, and that it had, like the Soviet Union, revolutionized and liberated itself from within. For them, Leipzig was an opportunity to display not only where they were, but above all where they were going to be in the near future: an industrialised nation that had rid itself of the shackles of imperialism and feudalism.

China's ideological aspirations mapped poorly onto the exhibition blueprints and organisational schedules of the Leipzig Fair Office. The problem was not the amount but the kind of space China required. In December 1951 the Fair Office informed the Chinese Diplomatic Mission that it had reserved 3180 square meters on the first floor of Hall X

\footnotetext{
${ }^{34}$ StA-L, 21000 VEB LMA (II), No. 139, Leipziger Messeamt, 'Zhongguoguan - cong yijiuwuyi dao yijiuwuliu [The China Pavilion - From 1951 to 1956]', Leipziger Messemagazin, Chinese edition, May $1957,1$.
} 
for China for the 1952 exhibition. ${ }^{35}$ China's second exhibition was going to be expansive, and exceed those of all other socialist nations in the Hall. ${ }^{36}$ To the surprise of all, Jia Shi then notified the MAI in late May 1952, three months before the fair, that the Chinese exhibition would include 50 to 60 medium and large machines. China, he wrote, was prepared to occupy five to seven thousand square meters, and 'if possible an own hall'. This was both unexpected and a problem for the fair office. Selmanagic advised that the first floor of Hall X could not possible hold heavy machines, so a new space was needed. Although this put the Fair Office's plans in total disarray, the MAI decided: 'We recommend trying everything to fulfil these wishes. We believe this is politically necessary'. ${ }^{37}$ China should have space to exhibit heavy machinery, the material proof of its new sovereignty and progress.

The MAI's decision was smart diplomacy, as the GDR government had built its own legitimacy on a fervent rhetoric of anti-imperialism. ${ }^{38}$ But it created the perfect logistical storm for the fair office. Schubert investigated, baffled by the Chinese assurance that they had mentioned their intention not to exhibit in Hall X shortly after the 1951 fair. Reporting to the MAI, he wrote that nobody knew anything about the Chinese making such an 'expression of opinion' (Meinungsäußerung). China had had the blueprints for months, why Schubert wrote, had there not been 'even a hint that China desired a

\footnotetext{
${ }^{35}$ StA-L, 21000 VEB LMA (II), No. 1282, Letter to the Diplomatic Mission 'Betr: Leipziger Messe 1952', 18 December 1951.

${ }^{36}$ In early May, four months before the fair's opening date, the head of the fair office, Schubert, sent a description of Hall X via airmail to China. StA-L, 21000 VEB LMA (II), No. 1282, Letter by Schubert to the PRC Ministry of Foreign Affairs, 'Betr: Leipziger Messe 1952', 5 May 1952.

${ }^{37}$ StA-L, 21000 VEB LMA (II), No. 1282, 'Abschrift Ministerium für Innerdeutschen Handel, Außenhandel, von China Abteilung an Abt. Werbung und Messen. Betr: Mitteilung aus Peking', 27 May 1952.

${ }^{38}$ GDR anti-imperialism is discussed in W. G. Gray, Germany's Cold War. The Global Campaign to Isolate East Germany 1949-1969 (Chapel Hill, 2003); C. Jetzlsperger, "Die Emanzipation der Entwicklungspolitik von der Hallstein-Doktrin. Die Krise der deutschen Nahostpolitik von 1965, die Entwicklungspolitik und der Ost-West-Konflikt," Historisches Jahrbuch, vol. 121 (2001), 320-366; Y. Hong, Cold War Germany, the Third World, and the Global Humanitarian Regime (Cambridge, 2016); S. Gehrig, 'Reaching Out to the Third World: East Germany's Anti-Apartheid and Socialist Human Rights Campaign', German History (online first); U. Engel and H. Schleicher, Die beiden deutschen Staaten in Afrika. Zwischen Konkurrenz und Koexistenz 1949-1990 (Hamburg, 1998).
} 
fundamental change'? ${ }^{39}$ Now several exhibitions had to be reorganised. The MAI determined that China should get the newly-built Hall E. Situated at the centre of the fair grounds with some 3061 square meters net exhibition space, the hall was one of the brightest and nicest of the fairs, in close proximity to the Soviet pavilion. ${ }^{40}$ Foodstuff and luxury foods would vacate Hall E and move to Hall IX, and Cinema-Photo-Optics would move to the first floor of Hall X, China's original space. ${ }^{41}$ Machines for display that had already been delivered to the originally allotted spaces had to be moved to their new home. ${ }^{42}$ Affected businesses would be unhappy, as would other socialist countries that had lobbied for further exhibition space. ${ }^{43}$ China's material presence and demands were spatially impinging on the GDR's relations with other countries.

Logistics were one reason why the fair office had not anticipated that China would want to exhibit heavy machinery. The scale of preparations now needed was immense. Anxiously, the Chinese government requested that the fair's opening date be delayed; but the fair office explained that this would severely damage other exhibitors. ${ }^{44}$ Scrambling to deliver, Beijing swiftly selected exhibition items from the country's leading manufacturers. In late July, the first train left Beijing. Made up of eleven carriages carrying 487,322 cubic meters of goods in 294 crates, the train moved to the Soviet and then the Polish border at Frankfurt-Oder. The second train, with 701 crates and 295

\footnotetext{
${ }^{39}$ StA-L, 21000 VEB LMA (II), No. 1282, 'Volksrepublik China als Aussteller von Maschinen', 14 June 1952.

${ }^{40}$ StA-L, 21000 VEB LMA (II), No. 1282, Airmail letter to PRC Ministry of Foreign Trade, 'Re: Participation in the Leipzig Fair 1952 (7th to 17th September)', 16 June 1952.

${ }^{41}$ StA-L, 21000 VEB LMA (II), No. 1282, Letter from the GDR Ministry of Foreign and Innergerman Trade to the Leipzig Fair Office, 'Betr: Ausstellungsraum für die Volksrepulbik China zur Leipziger Herbstmesse 1952', 13 June 1952. StA-L, 21000 VEB LMA (II), No. 1282, Letter Leipzig Fairs Office to the GDR Ministry for Machineengineering, 'Betr: Ausstellungsraum für die Volksrepublik China zur Leipziger Messe 1952', 19 June 1952.

${ }^{42}$ StA-L, 21000 VEB LMA (II), No. 1282, Letter from the MAI Abtl. Werben und Messen to the Leipzig Fair Office, 'Betreff: Ausstellungsräume für die Volksrepublik China zur Leipziger Messe', 13 June 1952.

${ }^{43}$ They would not be compensated for financial losses, although the fair office did state that they would seek to 'give them all imaginable and possible help to cope with the situation'. StA-L, 21000 VEB LMA (II), No. 1282, Letter Leipzig Fair Office to the GDR Ministry for Machineengineering, 'Betr: Ausstellungsraum für die Volksrepublik China zur Leipziger Messe 1952', 19 June 1952.

${ }^{44}$ StA-L, 21000 VEB LMA (II), No. 1282, 'Ergänzungen zur Leipziger Messe', 11 June 1952.
} 
metric tones of goods, including disassembled heavy machinery, departed in early August. ${ }^{45}$ At every border, goods passed through customs and were reloaded onto new trains. ${ }^{46}$ Upon arrival, unpacking and reconstructing machines took about 300 days worth of work. Thirty machines were to be shown in constant operation, and ten machines had dedicated staff that would give demonstrations. Three members of China's forty people strong fair delegation travelled to Leipzig in August already, to help with these preparations and to supervise the printing of over 200 photos and 20 statistical tables for the exhibition. ${ }^{47}$ The remaining delegation members followed later, including party officials, two cooks, ten skilled workers to help with specific machines, the 20 -year old labour model Xuan Fengzhi who could administer 1200 spindles at once, and Xinhua journalists to report on their country's performance. ${ }^{48}$

If the logistics of the 1952 pavilion were elaborate, successive exhibitions in the following years only increased the number of delegates sent and items shipped, making the construction of the China Pavilion one of the largest tasks of the annual fair. The PRC government nonetheless considered it a worthy investment of time, funds, and energy. Already in 1952, following the chaotic scramble to set up the China Pavilion, trade commissioner Türpe wrote to East Berlin from Beijing to say that 'the Chinese friends were very pleased with the overall result' of their new exhibition. ${ }^{49}$ By 1954 , the Leipzig Fair Office noted in an internal discussion memo that the China pavilion had been the most visited of all that year, with an average of about 100 businessmen negotiating in the

\footnotetext{
${ }^{45}$ StA-L, 21000 VEB LMA (II), No. 1282, 'Übersetzung, Brief vom China-Komittee for the Promotion of International Trade an den deutschen Handelsrat Herr Türpe', 31 July 1952, and StA-L, 21000 VEB LMA (II), No. 1282, Letter Tschen Min to Handelsrat Türpe, 'Abschrift, Übersetzung', 6 August 1952. ${ }^{46}$ StA-L, 21000 VEB LMA (II), No. 1282, 'Übersetzung, Brief vom China-Komitee for the Promotion of International Trade an deutschen Handelsrat Herrn Türpe', 31 July 1952.

${ }^{47}$ StA-L, 21000 VEB LMA (II), No. 1282, 'Ergänzungen zur Leipziger Messe', 11 June 1952, and StAL, 21000 VEB LMA (II), No. 1282, 'Abschrift, MAI HA Handelspolitik, Abt. China, An Abt. Werbung und Messen im Hause, Betr: Telegramm aus Peking', 28 July 1952.

${ }^{48}$ StA-L, 21000 VEB LMA (II), No. 1282, 'Abschrift, Von Abt. China an Abt. Werbung und Messen'. 19 August 1952.

${ }^{49}$ StA-L, 21000 VEB LMA (II), No. 1282, 'Auszug aus dem Bericht des Handelsrats Türpe über die Besprechung mit Herrn Chen-Min, Leiter der Leipziger Messe-Delegation vom Komitee zur Förderung des Internationalen HAndels am 21. November 1952', 19 December 1952.
} 
pavilion every day. ${ }^{50}$ Writing from East Berlin, Xinhua reporters estimated that the Chinese delegation that year had come into contact with more than 2000 people from some 100 firms from the trade worlds of some 21 socialist and non-socialist countries, closing deals of almost ten million UK pounds ${ }^{51}$ Exhibiting at Leipzig had become part of the PRC's wider global exhibition work, which took delegations to Pakistan, India, the Soviet Union, Poland, France, and other countries.

[line break]

A closer look at the interior and exterior of the Pavilion over the years starting in 1952 reveals how the Chinese delegation, its team of architects and workers led by Zhang Ding and Selmanagic, and the Leipzig Fair Office tried to give visitors a chance to experience 'New China' (Xin Zhongguo). The pavilion announced itself to visitors from afar with imported man-sized Chinese characters. They spelled out 'People's Republic of China' and were attached onto an obelisk several meters high. ${ }^{52}$ Just outside the pavilion, the walkway was decorated with white lanterns, designed by Zhang Ding. Surrounded by heavy machinery exhibited in front of the pavilion, visitors could take a rest on foldable easy chairs. Inside, decorative lamps made especially for the exhibition brightened the walkways. Dozens of meters of colourful Chinese silk cascaded from high ceilings. ${ }^{53}$ Bamboo vitrines with elaborate ornamental weaving were situated next to an artificial Chinese garden assembly with a small river and plants that showed off agricultural products. Visitors could take in this scenery to the background of 'Gentle Chinese music'. $^{54}$

\footnotetext{
${ }^{50}$ StA-L, 21000 VEB LMA (II), No. 641, Welcome speech to the Arbeitsbesprechung, 3 December 1954.

51 'Yijiuwusinian Laibixi guoji bolanhui bimu [Conclusion of the 1954 Leipzig international fair]', Guangming ribao, 23 September 1954, 4.

${ }^{52}$ StA-L, 21000 VEB LMA (II), No. 1282, Letter from Handelsrat bei der Diplomatischen Mission der DDR bei der Regierung der VR China to the Ministerium für Aussenhandel und Innerdeutschen Handel, Abtlg. China. 6 August 1952.

${ }^{53}$ StA-L, 21000 VEB LMA (II), No. 1282, 'Besprechung mit Minister Che, Herrn Tsen und Lo am 6.8.1952 im Messe- und Ausstellungsamt', 7 August1952.

${ }^{54}$ Huang Li, 'Guoji bolanhui zhi cheng - Laibixi [The international fair city - Leipzig]', Deguo manyi, (1958), 20-26, 22.
} 
Similar to other countries that tried to create a comprehensive sensual experience for visitors, the Chinese exhibition offered more than visuals, objects, and music. ${ }^{55}$ As of 1953, the Chinese National Tea Company invited visitors to try its teas and comment on feedback forms ${ }^{56}$ Wilhelm Pieck, the GDR's first state president, was treated to candied fruit at the end of his tour of the pavilion. ${ }^{57}$ Over the years, special sweets, teas, wines and foods were also on offer for the privileged guests invited to the annual evening reception in the pavilion. ${ }^{58}$ In 1952, two cooks, flown in from China, ran a restaurant in the Leipzig branch of the Paulanerbräu. To cook for ordinary and special visitors as well as for the Chinese delegation, they brought with them dried vegetables and special ingredients. ${ }^{59}$ In 1955, the Chinese restaurant had several cooks from different parts of China, serving up Beijing duck, Guangdong sweet and sour pork, steamed dumplings, and buns filled with fresh meat. ${ }^{60}$ The restaurant's chopsticks from China were so popular that guests took them home at the end of the meal as a souvenir, forcing the Chinese delegation to use some of the chopsticks from the exhibition as substitutes until new provisions arrived. ${ }^{61}$

Those GDR citizens who could shop at the China Importe (China Imports) could take the experience of the Chinese exhibitions home. China sent a range of everyday goods including rubber and leather shoes, pens, vases, tooth paste, enamel, pyjamas, silk and

\footnotetext{
${ }^{55}$ On food in exhibitions see M. Neuburger, 'Kebabche, Caviar or Hot Dog? Consuming the Cold War at the Plovdiv Fair 1947-72', Journal of Contemporary History, 47, 1 (2012), 48-68. But this tactic could also go wrong, see Pence, 'Showcasing Cold War Germany in Cairo'.

${ }^{56}$ StA-L, 21000 VEB LMA (II), No., blueprint of the feedback form, no date.

${ }^{57} \mathrm{Ji}$ Yin, 'The German people ardently love New China - Notes on the trip to Germany [Deguo renmin re'ai Xin Zhongguo - Lü De sanji]', Shijie zhishi, 1952, 19.

${ }^{58}$ See, for example, StA-L, 21000 VEB LMA (II), No. 632, 'Aktennotiz: Empfang China', 20 August 1953 and 'Guoji bolanhui zhicheng - Laibixi', 23.

${ }^{59}$ StA-L, 21000 VEB LMA (II), No. 1282, 'Aktennotiz: Telefonischer Anruf der Chinesischen Handelsmission am heutigen Tage', 19 August 1952. At first they also entertained the idea of bringing in the two cooks from West-Berlin, but in the end they formed part of the delegation that flew in from China, see StA-L, 21000 VEB LMA (II), No. 1282, 'Aktennotiz: Besprechung mit Herrn SchangKuang-Tou von der Chinesischen Mission in Berlin und seinem Dolmetscher anlässlich der Besprechung am 11.6.1952 auf dem Messegelände', 12 June 1952.

${ }^{60}$ 'Guoji bolanhui zhicheng - Laibixi', 23.

${ }^{61}$ Ibid.
} 
popelin shirts, bedlinen, sweets, leather bags, and pillow covers. ${ }^{62}$ China Importe exemplified the PRC government's intent to use light industry, handicraft, and agricultural products to make Communist China seem indispensable to the wider world. A picture of people walking in front of China-Importe was one of the few images of the Leipzig fair reprinted in Chinese newspapers (See Figure 2). It focused viewers' attention on the fashionable socialist female shopper in the front of people crowding outside of the store. ${ }^{63}$ This was another successful part of the fair that its organizers had neither initiated nor at first welcomed. China Importe were set up at the request of the Chinese Ministry of Trade which explicitly asked in 1952 to have over 300 crates of products made available to a 'wide circle' of the working population for purchase at basic prices that did not include special tariffs. ${ }^{64}$ If the Leipzig Fair Office had at first protested that this was 'not standard practice', the offers turned out to be so desirable that already by 1953 its own staff requested permits to purchase these goods. ${ }^{65}$

Not all Chinese exhibitions enjoyed similar success, however, and what defined a successful exhibition was up to debate. Opinions diverged on the merits of the 1956 exhibition, for example. For some, the exhibition had once again brought the marvels that visitors looked forward to annually: bamboo, wood and porcelain carvings, ivory and jade, including a jade tripod and an ivory ball of twenty-seven layers. Other objects included carved wood table lamps for the distinguished socialist worker's home, fur coats, and silk designs for clothing. ${ }^{66}$ While visitors continued to flock to the pavilion, however, some GDR observers commented that the exhibition was unorganised and the displays

\footnotetext{
${ }^{62}$ StA-L, 21000 VEB LMA (II), No. 1282, 'Telegramm aus China' to the HA-Handelspolitik, Abteilung China, 14 July 1952.

63 'Yijiuwusi nian Laibixi guoji bolanhui bimu [Conclusion of the 1954 Leipzig international fair]', Guangming ribao, 23 September 1954, 4. On luxury goods in the Eastern bloc see D. Crowley and S.E. Reid, Pleasures in Socialism: Leisure and Luxury in the Eastern Bloc (Evanston, 2010).

${ }^{64}$ StA-L, 21000 VEB LMA (II), No. 1282, Letter from Schubert to the MAI 'Betr: Übernahme von chinesischen Ausstellungsgütern', 13 August 1952.

${ }^{65}$ StA-L, 21000 VEB LMA (II) Letter from Schubert to the HO Warenhaus, 'Verkauf von Import-Ware der zur LEIPZIGER MESSE anwesenden ausländischen Aussteller', 25 August 1953.

${ }^{66}$ Politisches Archiv des Auswärtigen Amts (PA AA hereafter), MfAA, A 6544, 'Einführung in den chinesischen Pavillon auf der Leipziger Frühjahrsmesse 1956'.
} 
did not 'meet expectations'. Eggs, wool, feathers and other goods had been missing, and the strength of Chinese industrial products was not highlighted. It seems the delegation was aware of these issues, too. The MAI was able to confirm, either because someone from the Chinese delegation spoke to a colleague in confidence or because they bugged the delegation's hotel rooms, that delegation members had mentioned that 'the fair had not been taken seriously enough by those responsible in the PRC and that the preparations had accordingly been insufficient'. ${ }^{67}$

Much as in the first Chinese exhibition in 1951, moreover, the explicitly political bits often did not interest people as much as the prospect of goods. In 1954, for example, the Chinese delegation sent out dozens of invitations to a film screening in the Soviet Pavilion's cinema. Only six out of the forty invited members of the Fair Office and none of the invited guests from the MAI showed up; a PR disaster. The Chinese screening was aborted. When the film was re-screened a day later, there were 200 guests who, the Leipzig Fair Office was at pains to state in its official report, commented positively on the film. That such screenings and materials were not as popular, however, was also due to language barriers. The particular 1954 film was shown exclusively in Chinese, without any German introduction or texts, thereby making it - as the Leipzig Office commented less accessible. ${ }^{68}$ Here, as in other cases of Sino-GDR and pan-socialist cultural interactions, cultural products and political propaganda did not translate seamlessly just because its different audiences lived under similar political systems. ${ }^{69}$

\footnotetext{
${ }^{67}$ PA AA, MfAA, A 6544, 'An die Botschaft der Deutschen Demokratischen Republik in der VR China, Betr: Besprechung der Wirtschaftsreferenten und Besuch der Leipziger Messe', 9 Mai 1956. ${ }^{68}$ StA-L, 21000 VEB LMA (II), No. 640, ' Filmvorführung China am 14.9.54 in Kinosaal Sowjet Pavillon', 15 September 1954, StA-L, 21000 VEB LMA (II), No. 640, 'Filmvorführung China am 15.9.54 18 Uhr - Kinosaal Sowjet Pavillon', 16 September 1954, and StA-L, 21000 VEB LMA (II), No. 640, 'Kleiner Empfang China für Mitarbeiter im Anschluss an Kinovorstellung, 15.9.54', 16 September 1954.

${ }^{69}$ N. Volland, 'Translating the Socialist State'; T. M. Chen, "Film and Gender in Sino-Soviet Cultural Exchange, 1949-1969", in: H. Li and T. Bernstein, ed., China Learns from the Soviet Union, 1949 to the present (Lanham 2010), 421-45; T. M. Chen, "International Film Circuits and Global Imaginaries in the People's Republic of China, 1949-1957," Journal of Chinese Cinemas 3.2 (2009): 149-61.
} 
The design of the pavilion also remained a challenge over the years. Selmanagic and Zhang Ding's collaboration was productive but they also continued to have 'differences of opinion'. As one report wrote in 1952, the Chinese delegation 'wished for their pavilion...to have an explicitly Chinese character despite its European architecture'. ${ }^{70}$ If getting different teams from different countries to communicate was a challenge, so was the fact that the design of the pavilion each year was part of shifting national discussions in China about what good Chinese architecture and design should look like on the road towards socialism. ${ }^{71}$ The 1954 pavilion was encased in modular decorations to make it look noticeably Chinese, with replicas of decorated ridges, colourful eaves, paper lanterns, and white balustrades (See Figure 3).$^{72}$ Only four years later these kinds of ornamental styles were considered inappropriate and too traditional for a country that was in the course of establishing socialism. Hall $\mathrm{E}$ was, at the request of the Chinese organisers, stripped back to its plain modernist shell of concrete, metal, and glass (See Figure 4$).^{73}$

[line break]

The late 1950s opened a new phase in the history of Chinese exhibitions as the pavilion became source of a new kind of anxiety. The PRC government was confident in 1957. It passed the second five-year plan that year which emphasized a push for heavy industry, and it embarked on the Great Leap Forward campaign a year later. As for Leipzig, the China Committee for the Promotion of International Trade reported that it had reached the long-desired balance of industry, agriculture and other products. Writing in the

\footnotetext{
${ }^{70}$ StA-L, 21000 VEB LMA (II), No. 1282, 'Auszug aus dem Bericht des Handelsrats Türpe über die Besprechung mit Herrn Chen-Min, Leiter der Leipziger Messe-Delegation vom Komitee zur Förderung des Internationalen Handels am 21. November 1952', 19 December 1952.

${ }^{71}$ On the discussion of 'national form' see Z. Tao, 'Building Big, with No Regret: From Beijing's "Ten Great Buildings" in the 1950s to China's Megaprojects today', in J. Li and E. Zhang, eds, Red Legacies in China. Cultural Afterlives of the Communist Revolution (Cambridge MA, 2016), 56-84.

72 On Zhang Ding's involvement in the early designs of the pavilion consult C. Ho, 'Design technocrats: Zhang Ding (1917-2012) and the Leipzig Fairs, 1951-1954', Paper presented at the Association of Asian Studies (AAS) Annual Conference, Philadelphia, March 27-30, 2014, cited with permission. ${ }^{73}$ StA-L, 21000 VEB LMA (II), No. 437, 'Aktennotiz - Betr: Besprechung über chinesische Kollektivausstellung, Halle 5, FM 1958', 10 January 1958.
} 
Leipziger Messe Magazine, the committee explained that for the 1957 spring fair: 'The scale and scope of the exhibition... will be $45 \%$ of the exhibition area for industrial products, $20 \%$ for agricultural and native products; $20 \%$ for textiles and light industrial products; and $15 \%$ for handicraft and printing products'. ${ }^{74}$ While trade and technologicalscientific exchanges continued, however, the impact of Khrushchev's secret speeches of February 1956 was slowly felt across Sino-Soviet and Sino-GDR interactions, making the work of the Leipzig Fair Office, the MAI, the Chinese Ministry of Trade, the Chinese Committee for the Promotion of International Trade, and successive Chinese delegations increasingly more difficult to navigate. ${ }^{75}$

At the same time, the PRC put on its largest exhibition in 1959 and another sizeable exhibition in $1960 .{ }^{76}$ The 1959 spring fair was guided by the Great Leap Forward's central slogan 'walking on two legs' of industry and agriculture. China sent a several meter high model steel furnace to demonstrate how the country planned to overtake Britain and the US in steel production in the near future. Visitors could also inspect one the PRC's first domestically produced cars, the famous Red Flag Limousine, exhibited on a rotating pedestal (See Figure 5). The Fair Office recorded 163 Chinese visitors, an unusually high number which included for the first time a group of Chinese tourists. The Great Leap Forward theme continued into 1960, when visitors and photographers' attention was drawn to the fanciful, 'original' (as one photographer called them), decorations of the China pavilion. Oversized cotton buds and replicas of grain stalks were staged in flower-like arrangements half a meter to a meter in size to demonstrate the abundance of grain, cotton, and other cereals and raw materials. ${ }^{77}$ So abundant was the

\footnotetext{
${ }^{74}$ Leipziger Messeamt, 'Chinese Pavillon in the Leipzig Spring Fair 1957', Leipziger Messemagazin, English edition, December 1956, 44.

${ }^{75}$ C. Jian, Mao's China and the Cold War, 49-84.

76 The 1959 exhibition covered 6200 square meters and the 1960 exhibition covered 3600 square meters (the latter was comparable in size to the 1954, 1955, and 1956 exhibitions), see Leipziger Messe $\mathrm{GmbH}$, Unternehmensarchiv, VR China, 'Messebeteiligung VR China (statistische Angaben). ${ }^{77}$ StA-L, 21000 VEB LMA (II), CVIII, Nr. 7722, Photo by Rössing-Winkler, Pressefotografen. This was a fashionable display design at the time that was also employed in the 1959 National Agricultural
} 
display of goods that an East German official pulled aside a Chinese reporter at one soirée to quietly ask whether Chinese people really had access to the kinds of goods on display in the China pavilion or whether everything was merely for show and export. ${ }^{78}$ It was a reasonable question given that most East German citizens by that point no longer expected to find East German goods displayed at Leipzig in their local stores.

Away from visitors' eyes, tensions were mounting. Some tensions resulted from the growing political frictions between China and the Soviet Union. Yet many stemmed from differences in approach, miscommunications, and disagreements that had existed throughout the 1950s but were now expressed more candidly. As in 1956, the Fair Office was unhappy with the layout of the 1958 spring fair exhibition, arguing that it did not 'reach the design level of previous exhibitions'. This time, however, they wrote in their report that it was 'expressed entirely candidly that we were not happy with the construction of the Chinese pavilion' and 'that the design has to be done more carefully at the next fair'. ${ }^{79}$

Design questions may have been a cover for something more substantial in this case.

The Fair Office was unhappy that the PRC had consistently failed to send a special delegation instructed to make official purchases. This failure suggested that China saw the fairs merely as an opportunity for political propaganda, carefully curated export, and fact-finding whereas the GDR wanted them to take Leipzig seriously as a marketplace for selling and buying products. ${ }^{80}$ The fair organizers also worried that having no such delegation from China gave the Fair's 'capitalist' critics unnecessary grounds to decry the fair as little more than socialist propaganda overall. China's reticence was all the more

Exhibition in Beijing, see Linye guang, ed., Linye jianshe de huihuang chengji [The glorious achievements of forestry construction] (Beijing 1960).

${ }^{78}$ Neibu cankao ziliao [Internal Reference Materials], No. 2748, 10 April 1959, p. 16.

${ }^{79}$ StA-L, 21000 VEB LMA (II), No. 483, Letter from the Leipzig Fair Office to the Office of the Handelsrat 'Beteiligung der VR China an der Leipziger Messe 1959', 17 June 1958.

${ }^{80}$ StA-L, 21000 VEB LMA (II), No. 483, Letter from the Leipzig Fair Office to the Handelsrat Neubert at the GDR embassy in Beijing, 2 October 1957. On the selection of expert delegates to study newest developments in technology, at the fairs but also by visiting nearby factories and work units, see Shanghai Municipal Archives B76-3-349, 006, 'Zhongguo guoji maoyi cujin weiyuanhui qing xuanpai renyuan fu Laibixi canguan shi', 17 January 1959. 
frustrating given the fair office's intense advertising efforts. Every year, hundreds of invitation letters went out to companies across China hoping to persuade them to participate. Someone had to write addresses, either by hand or using the one single Chinese typewriter housed in the East Asian Institute of the Karl-Marx University. ${ }^{81}$ This took days, yet it had no visible effect. Participation in the fairs remained under the tight centralised control of the Committee for the Promotion of International Trade that did not wish to change their approach.

For the Fair Office, then, the growing alienation and hostilities between the Soviet Union and the PRC were bad news for specific reasons. Already before the split, it had been laborious to organise the Chinese exhibitions and get the PRC to involve itself in a way the organizers deemed adequate. Now it was to become worse. Still, the Fair Office and the MAI wanted and needed China to participate. They believed that a strong showing from socialist countries was vital to maintain the appearance of the GDR as a politically viable and economically strong state during a time of acute crisis: more and more East Germans were fleeing to the West, leading to the construction of the Berlin Wall in 1961, and in 1962 NATO demanded that member states boycott the Leipzig Fairs in the wake of the Cuban Missile Crisis. ${ }^{82}$ The raison-d'être of the Leipzig Fairs as the trading place between East and West had seldom been more in jeopardy.

[line break]

In this context, China's presence at Leipzig became a material manifestation of the deep uncertainties and competing priorities within the GDR leadership about what to do with a

\footnotetext{
${ }^{81}$ It was, however, not always easy to find someone (usually a study abroad student) who could operate this machine, see StA-L, 21000 VEB LMA (II), No. 483, Letter from the Leipzig Fair Office to the GDR Embassy in Beijing 'Individuelle Werbung in der VR China', 23 July 1958. On the complicated history of the Chinese typewriter (and why finding a typist was not easy) see Thomas S. Mullaney, The Chinese Typewriter: a global history (Cambridge, MA 2017).

${ }^{82}$ P. Major, 'Innenpolitische Aspekte der zweiten Berlinkrise (1958-1961)', in H. Hertle, K. Jarausch, and C. Kleßmann, eds, Mauerbau und Mauerfall: Ursachen, Verlauf, Auswirkungen (Berlin 2002), 97110; P. Major, Behind the Berlin Wall: East Germany and the Frontiers of Power (Oxford 2010), 23116.
} 
country they considered a political troublemaker but desirable trading partner. ${ }^{83}$ The advantage of the Leipzig fairs as an 'economic-political exhibition' had turned into a double-edged sword. Focus on mutual economic interests allowed everyone, when they so wished, to continue pan-socialist interactions at Leipzig. For this reason, the fairs remained one of the few spaces of fairly regular contact between China, the Soviet Union, and other socialist states. Yet because the economic and the political were closely linked, the fairs became grounds for the contestation over the direction of world socialism.

Such contestation erupted in late 1960 over the question what China could exhibit in 1961. As part of its continued exhibition of the Great Leap Forward, and its industrial and agricultural policies and production, China wished to show images and tell stories about people's communes. In December 1960, the PRC Minister of Foreign Affairs had his deputy inform the GDR government that the PRC government looked forward to 'actively participating' in the upcoming 1961 spring fair and that it would show the successes of the Leap and the people's communes. Visitors would see that China's people's communes were the successful materialization of socialism. Anticipating controversy, the minister added: 'this does not mean, that we will force our point of view onto anyone'. ${ }^{84}$

It was a thorny issue for the Fair Office. Nikita Khrushchev had criticized China's people's communes in July 1959, and there had been heated discussions about how to deal with China's people's communes in other parts of the GDR in previous months. ${ }^{85}$ Worried about getting caught in this debate, the fair office asked the 'Chinese comrades' to 'design the exhibition in a way that it will not advocate organisational forms, such as the people's communes, as internationally applicable'. Cautiously it added 'the GDR

\footnotetext{
${ }^{83}$ S. Urbansky and M. Trecker, 'Kremlinology revisited: the nuances of reporting on China in the Eastern bloc press', Cold War History 18, 3 (2018): 307-24.

${ }^{84}$ PA AA, MfAA, A 6837, Letter from Wenning, Peking, to Minister Schwab, 10 December 1960.

${ }^{85}$ The controversy surrounding the people's communes is discussed in Urbansky and Trecker, 'Kremlinology revisited', 8, and Jersild, 'Socialist exhibits and Sino-Soviet relations', 285-287. See also, M. Wobst, Die Kulturbeziehungen zwischen der DDR und der VR China 1949-1990. Kulturelle Diversität und politische Positionierung (Münster, 2004); Q. Slobodian, "The Maoist Enemy"; Meißner, ed., Die DDR und China 1949 bis 1990, 101-40.
} 
government does not intend to criticize China's people's communes'. A further sentence, deleted in the final version, revealed the actual problem: 'It [The GDR government] considers this organisational form as inappropriate for the GDR because it would be a step back compared to the development the GDR has already achieved'. ${ }^{86}$

The official, cryptic language resulted in numerous discussions and letter exchanges between Berlin and Beijing. The Chinese argued they could not exhibit without the people's communes because that would be akin to 'not showing the party and government line of the GDR in any GDR exhibition'. ${ }^{87}$ To them, a rejection of their plans to celebrate the communes only suggested once more that the GDR, the Soviet Union, and other socialist states considered Chinese socialism inferior (as indeed they did). The Fair Office worried that such a celebration would upset the ideological balance of the fair. Worse, approval of any exhibition that endorsed people's communes risked suggesting to East German visitors that the SED's talk about advanced socialism might conceal plans to go down the path of communes as well.

In the end, a reduced Chinese exhibition of some 2000 square meters in 1961 mentioned the communes but focused on industrial products. ${ }^{88}$ Even with this concession, GDR Ministry of Foreign Affairs officials were still unhappy, concluding that the smaller scale meant the Chinese had not considered the exhibition as important. But this was not how the Chinese saw it. ${ }^{89}$ A report by delegation member Yan Jiwu, an official in the Beijing Municipal People's Committee, told of the great variety of objects, 2900 different kinds in total, that had been shipped to Leipzig for the exhibition. China's Panda-brand radio in particular garnered attention, the report wrote, and the textiles had East Germany's women expressing admiration, as every year. Not only had China exhibited

\footnotetext{
${ }^{86}$ PA AA, MfAA, A 6837, 'Entwurf einer Antwort zur Mittelung aus Peking betr. Beteiligung China an der Leipziger FM 1961'.

${ }^{87}$ PA AA, MfAA, A 6837, 'Aktenvermerk über eine Besprechung mit dem Stellvertreter des Aussenministers, Genossen Tsöng Jung-tjian, am 10.12.1960', 14 December 1960.

${ }^{88}$ PA AA, MfAA, A 6813, 'Aktenvermerk über die Besichtigung der Ausstellung der VR China auf der Leipziger Frühjahrsmesse', 13 March 1961.

${ }^{89}$ Ibid.
} 
successfully in Yan's opinion, its 'colourful products interested everyone and made many want to buy products'. ${ }^{90}$ All the more frustrating that items came without any indication of price, leading, Yan wrote, one visitor to want to buy one carpet for 2000 dollars. To be sure, Yan identified some faults with the exhibition: the design could have been better, the textile arrangement was messy, and the lighting not ideal. It also did not help that some items were insufficiently wrapped, so that one blast furnace model broke on the trip to Leipzig. Overall, though, Yan considered the exhibition a success.

The significance of the Chinese exhibition was therefore a matter of perspective. Few people, moreover, knew how things would develop from one year to the next. Yan expected China to exhibit in the following year. Yet it would take until 1965. In the intervening years, China continued to send delegations - now often made up of lowranking officials and scientific experts. As the GDR Ministry of Foreign Affairs noted, this was mostly done to 'make use of the advantageous situation' to get to know the global situation of technical and industrial development. ${ }^{91}$ Indeed, reports marked for 'internal circulation' were distributed in China detailing exactly what delegation members had seen and how it might be relevant to China's future development in key areas of chemical industries, heavy but also light industry. ${ }^{92}$ GDR ministry officials, meanwhile, tried to impress on delegates why China should wish to participate more extensively in the fair and export more to the GDR, rather than focusing, as they felt China was, on trading with 'imperialist and young nation-states'. ${ }^{93}$

The ministry's plans were not aided by the occasional diplomatic éclat. At a reception of ministers hosted by the GDR for the spring fairs in 1963, nobody spoke to the Chinese

\footnotetext{
${ }^{90}$ Beijing Municipal Archives 2-20-876, 'Canjia yijiuliuyi nian Laibixi chunji guoji bolanhui gongzuo zongjie [Summary work report on participation in the 1961 international Leipzig spring fair]', May 1961, p. 062-066, p. 064. The report noted at the same time that the exhibitions of the Soviet Union, Poland, Bulgaria, and Czechoslovakia had featured fewer objects than in previous years ${ }^{91}$ PA AA, MfAA, A 6813, 'Gesamtbericht zur Leipziger Frühjahrsmesse', 20 March 1964.

${ }^{92}$ Zhongguo kexue jishu qingbao yanjiusuo, 'Chuguo canguan kaocha baogao [Report on an observation and study tour abroad]', October 1965 and Zhongguo kexue jishu qingbao yanjiusuo, '1965 nian Laibixi chunji bolanhui canguan jiyao [Record of the visit to the 1965 Leipzig spring fair]', July 1965.

${ }^{93}$ PA AA, MfAA, A 6813, 'Gesamtbericht zur Leipziger Frühjahrsmesse'.
} 
head of the delegation, and he left after an hour. ${ }^{94} \mathrm{~A}$ few months later, in September 1963, a Xinhua reporter got into a verbal fight with an official at the Leipzig autumn fair's press conference. China had just decided to cancel some of its orders for entire factories, a decision that was followed by an official statement from the GDR government that China's decision had caused 'heavy damage' to the GDR's economy. At the press conference, the GDR government official giving the statement and responding to questions explained - 'very rationally' as he emphasised - that 'any expert' would know that cancelling factory complexes was not the same as changing the specifications of raw material, agricultural, and light industry exports of the kind that China provided for the GDR. China, he suggested, lacked such understanding as a result of having only recently industrialised; a sharp reminder of China's position in the Marxist developmental model. Offended, the Xinhua reporter argued that the PRC had always supported the GDR in its political endeavours, and that the basis for trade amongst socialist nations should be actual need. ${ }^{95}$ A few months later, in March 1964, the Chinese delegation was the only one not to be given an interpreter for the official opening ceremony of the fair in the city's new opera house; leading the head of the delegation to remind his hosts that Chinese was the language of one quarter of the world population. ${ }^{96}$

The year 1965 seemed to mark a fresh start for Chinese exhibitions, however. For the first time, the Fair Office hosted an official Chinese government delegation with a full program of fair events and trips to factories nearby. Ministry officials in East Berlin prepared generous host gifts ranging from cameras to binoculars, paintings, and clocks. ${ }^{97}$ While ministry officials cautioned against what they called China's 'politics of

\footnotetext{
94 The GDR Ministry of Foreign Affairs commented on this occasion that there was 'a real possibility that such shortcomings could lead people to make far-reaching political conclusions.' PA AA, MfAA, A 6813, 'Bericht über die Leipziger Frühjahrsmesse 1963', 23 March 1963.

95 PA AA, MfAA, A 6813, 'Auszug aus dem Protokoll der Pressekonferenz zur Leipziger Herbstmesse am 3.0.1963 (stenografische Aufzeichung - nicht redigiert)', no date.

${ }^{96}$ PA AA, MfAA, A 6813, 'Bericht über den Besuch der Regierungsdelegation der VR China anläßlich der Leipziger Frühjahrsmesse 1964 in Leipzig', 6 March 1964.

${ }^{97}$ Gifts were calibrated carefully according to party rank, see PA AA, MfAA, A 6813, 031-35, 'Programm für die Betreuung der Regierungsdelegation der VR China zur LFM 1965', 24 February 1965
} 
differentiation' - meaning the attempt to be friendly to some socialist countries while continuing to criticize the Soviet Union - and against China's offer to 'develop state and economic relations between the GDR and the PRC despite differences of opinion', they also commented that the anniversary fair was a good opportunity to prove to China the GDR's 'honest intentions to develop relations further'. ${ }^{98}$ What exactly that would mean was likely unclear to many, but small tokens suggested the possibility of better relations: the Chinese delegation visited the Soviet Pavilion after the Soviet delegation paid the Chinese exhibition a visit, they also praised the Leipzig Fairs as an 'important international fair', and they took part in all official events. Mention of any problems relating to the Soviet Union, as a report commented, was 'mostly avoided'.${ }^{99}$ From the limited perspective of the Fair Office, a détente on the fair grounds seemed in reach. But was not to be. China exhibited in 1966, but the Cultural Revolution broke out later that year. The PRC would not exhibit again until the early 1970s after which it became, once again, a regular participant, now in the new climate of China's economic reform and internationalization.

[line break]

Reconstructing the history of China's exhibitions on the Leipzig fair grounds during the 1950s and 1960s has several analytical merits. It shows how the fairs - as a space for regular interaction - formed part of and shaped Sino-foreign interactions during the years predating the Cultural Revolution. Chinese trade exhibitions were one element in a complex network of spaces and events outside of China at which Chinese citizens and citizens from other countries interacted. Seen in conjunction with other such experiences and contacts, including scientific-technical cooperation, artistic and cultural exchanges, trade delegations, sports events, and the exchange and training of students, they can provide richer insight into the social and cultural dimensions of the country's international

\footnotetext{
${ }^{98}$ PA AA, MfAA, C 922/76, 'Bericht über den Aufenthalt der Regierungsdelegation der VR China zur Leipziger Jubiläumsmesse 1965', 18 March 1965.

${ }^{99}$ Ibid.
} 
engagement. In addition to throwing more light on the work of party and government officials (the classic agents of diplomatic and political history), such an approach foregrounds the work and role of architects, artists, construction workers, secretaries, model workers, cooks, student translators, exhibition visitors and others. Including the diversity of historical actors and local decision-makers is a reminder that the Sino-Soviet split was a process involving a range of people beyond senior leadership who created, mediated, reinforced or softened the "split" as they tried to put into practice the guidelines they had been given. ${ }^{100}$ As the case of China's involvement in Leipzig shows, the situation (and how it was interpreted) could change from month to month and from year to year, and the symbolic presence of China remained important to the GDR even when relations otherwise deteriorated.

This article has also illustrated why people and objects should be studied in conjunction when exploring Sino-foreign exchanges during the Cold War. Materiality can be a helpful lens through which to analyse competing aims and visions of socialist unity. Objects of all kinds - exhibition items, display furniture, decorative materials but also everyday items such as telephones, typewriters, transport boxes - allowed for the Chinese exhibitions to become a space for different people to interact. Objects had the power to consolidate cross-cultural relations or create tension, as they already had in Chinese exhibitions abroad during the late Qing and Republican period. ${ }^{101}$ They helped materialize Communist China for ordinary individuals - be they businessmen, local officials, housewives, young pioneers, or others. And they contributed to negotiating the country's position in the wider world.

A focus on exhibitions and questions of materiality finally also raises questions about the dominance of political periodisation in discussions of Sino-foreign contacts. If

\footnotetext{
${ }^{100}$ On the role of other groups of people as mediators in Sino-foreign relations before and after the split see A. Ghosh, 'Before 1962: The Case for 1950s China-India History, Journal of Asian Studies, vol. 76, no. 3 (2017): 697-727; Barrett, 'China's 'People's Diplomacy", Shuman, "From Soviet Kin to AfroAsian Leader"; Shuman,"Friendship is solidarity".

${ }^{101}$ S.R. Fernsebner, 'Material Modernities: China's Participation in World's Fairs and Expositions'.
} 
materiality structured perceptions across countries and cultures, this process did not unfold in lockstep with political developments, alliances, and breaks. Many objects were goods to be traded, desired, and - for the lucky ones - purchased and consumed, and those who obtained Chinese products at the China Importe or elsewhere often kept them well after political alliances had deteriorated; an aspect this article could not elaborate on. Here, too, China's presence at Leipzig - but also at other major trade fairs in the Soviet Union, Poland, France, and so on - shaped how people came to associate certain goods with the new Chinese government (even if the same goods had been available already before Communist rule in China). Exhibitions exerted a longer-term influence on popular ideas about the quality - positive or negative - and desirability of goods made in 'socialist China'. Even as many people in China could not access goods because of severe shortages, the same goods - mediated and exported also via fairs - wrote Mao's China into the international material history of objects 'made in China'. 